\title{
Pakistan's Agricultural Development since Independence: Intertemporal Trends and Explanations
}

\section{GHAFFAR CHAUDHRY and GHULAM MUSTAFA CHAUDHRY}

\begin{abstract}
The main objective of this paper has been to review Pakistan's historical experience in agricultural development in terms of growth, income distribution, and rural poverty. While the long-term growth rates between 1949-50 and 1994-95 were satisfactory, the variations around the average have been rather too large over the various decades. Beginning with a stagnating sector of the 1950s, agriculture witnessed record growth rates during the Sixties. This was followed by the lowest growth rates of the early Seventies, and acceleration in the second half of the Seventies. The experience since 1979-80 has been mixed, but the growth rates have been rather low through the Eighties and the Nineties. The trends in income distribution and poverty varied directly in relation to the agricultural growth rates, especially when they were in excess of the threshold level of 4.5-5.0 percent per annum. In general, a growth rate of 5.0 percent or higher has induced positive changes in income distribution and poverty. In view of this positive association, the pursuit of a high growth policy in agriculture should guide Pakistan's future development strategy. The efficiency of resource use, a greater dependence on modern technologies, and a minimisation of government intervention in the market mechanism are the essential pillars of the high growth strategy.
\end{abstract}

Agricultural development in Pakistan since the Fifties is the subject of discussion in this paper, which is divided into 5 sections. Section 2 follows Section 1 and reviews the historical growth pattern of the agricultural sector. The trends in income distribution and poverty are related in Section 3. In Section 4 the causes and consequences underlying this development experience are discussed with an emphasis on technology and agricultural prices. The concluding section makes policy recommendations for better prospects of agricultural development.

\section{HISTORICAL GROWTH OF AGRICULTURAL PRODUCTION}

Because of the primacy of the agricultural sector, sustained growth of production in agriculture has been a cherished goal of Pakistan's economy throughout its history. The relative growth performance of agriculture and subsectors is summarised in Table 1.

Two broad conclusions can be derived from the table. Firstly, the agricultural sector has maintained a long-term growth rate of 3.28 percent per annum between 1949-

M. Ghaffar Chaudhry is Joint Director and Ghulam Mustafa Chaudhry is Staff Economist at the Pakistan Institute of Development Economics, Islamabad. 
Table 1

Output Trends and Growth Rates of Agriculture and Its Sub-sectors from 1949-50 to 1994-95

\begin{tabular}{|c|c|c|c|c|c|c|c|c|c|c|c|}
\hline \multirow[b]{2}{*}{ Years } & \multicolumn{3}{|c|}{$\begin{array}{c}\text { Value-added at Constant Factor Cost of } \\
1959-60 \text { (Rs Billion) }\end{array}$} & \multicolumn{4}{|c|}{ Output (Million Tonnes) of } & \multicolumn{3}{|c|}{ Livestock Products (000 Tonnes) } & \multirow{2}{*}{$\begin{array}{l}\text { Eggs } \\
\text { (Nos. } \\
\text { Million) }\end{array}$} \\
\hline & Agriculture & Crop & Livestock & Wheat & Cotton & Cane & $\overline{\text { Rice }}$ & Milk & $\begin{array}{c}\text { Animal } \\
\text { Meats }\end{array}$ & $\begin{array}{l}\text { Poultry } \\
\text { Meats }\end{array}$ & \\
\hline \multicolumn{12}{|c|}{ A. Output Levels } \\
\hline 1949-50 & 6.60 & 4.25 & 2.29 & 3.92 & 0.22 & 7.85 & 0.81 & - & - & - & - \\
\hline 1954-55 & 6.95 & 4.32 & 2.25 & 3.19 & 0.28 & 8.84 & 0.84 & - & - & - & - \\
\hline 1959-60 & 7.71 & 4.77 & 2.84 & 3.91 & 0.29 & 10.64 & 1.00 & - & - & - & - \\
\hline 1964-65 & 9.28 & 6.02 & 3.12 & 4.59 & 0.38 & 18.67 & 1.35 & - & - & - & - \\
\hline 1969-70 & 12.57 & 8.92 & 3.44 & 7.29 & 0.54 & 26.37 & 2.40 & 7800 & 554 & 12 & 583 \\
\hline 1974-75 & 13.07 & 9.14 & 3.80 & 7.67 & 0.51 & 21.34 & 2.31 & 8173 & 622 & 34 & 1159 \\
\hline 1979-80 & 15.83 & 11.20 & 4.42 & 10.59 & 0.73 & 27.50 & 3.13 & 9075 & 740 & 49 & 2094 \\
\hline 1984-85 & 18.60 & 12.75 & 5.58 & 11.70 & 1.01 & 32.14 & 3.32 & 10856 & 980 & 99 & 4093 \\
\hline 1989-90 & 23.26 & 15.29 & 7.51 & 14.32 & 1.46 & 35.49 & 3.22 & 14723 & 1350 & 157 & 4670 \\
\hline 1994-95 & 28.21 & 17.74 & 9.91 & 17.00 & 1.48 & 47.17 & 3.45 & 18946 & 1806 & 308 & 5929 \\
\hline 1995-96 & 29.70 & 18.81 & 10.47 & 16.91 & 1.80 & 46.23 & 3.97 & 18919 & 1916 & 335 & 5757 \\
\hline 1996-97 & 29.91 & 18.40 & 11.15 & 16.38 & 1.60 & 42.00 & 4.30 & 20950 & 2032 & 385 & 5915 \\
\hline \multicolumn{12}{|c|}{ B. Annual Growth Rates (\%age) } \\
\hline $1950-55$ & 1.01 & 0.33 & 2.35 & $(4.04)$ & 4.94 & 2.40 & 0.73 & - & - & - & - \\
\hline $1955-60$ & 2.10 & 1.91 & 2.18 & 4.15 & 0.70 & 3.78 & 3.55 & - & - & - & - \\
\hline 1960-65 & 3.78 & 4.76 & 1.90 & 3.26 & 5.55 & 11.90 & 6.34 & - & - & - & - \\
\hline $1965-70$ & 6.26 & 8.18 & 1.97 & 9.69 & 7.28 & 7.15 & 12.19 & - & - & - & - \\
\hline $1970-75$ & 0.78 & 0.49 & 2.01 & 1.02 & (1.14) & $(4.14)$ & $(0.76)$ & 0.94 & 2.34 & 19.42 & 14.73 \\
\hline 1975-80 & 3.91 & 4.15 & 3.07 & 6.67 & 7.44 & 5.20 & 6.26 & 2.12 & 4.36 & 7,58 & 12.56 \\
\hline 1980-85 & 3.28 & 2.63 & 4.77 & 2.01 & 6.71 & 3.17 & 1.19 & 3.65 & 4.94 & 15.10 & 14.34 \\
\hline 1985-90 & 4.57 & 3.70 & 6.12 & 4.12 & 7.65 & 2.00 & $(0.61)$ & 6.28 & 6.62 & 9.66 & 2.67 \\
\hline 1990-95 & 3.93 & 3.02 & 5.70 & 3.49 & 0.27 & 12.89 & 1.39 & 5.17 & 5.99 & 14.43 & 4.88 \\
\hline $1995-97$ & 2.97 & 1.84 & 6.07 & $(1.84)$ & 3.98 & (5.64) & 11.64 & 5.05 & 6.07 & 11.80 & $(0.12)$ \\
\hline $1950-97$ & 3.28 & 3.23 & 3.43 & 3.31 & 4.33 & 4.06 & 3.27 & 3.61 & 4.84 & 13.16 & 9.72 \\
\hline
\end{tabular}

Source: Government of Pakistan (1986 and 1996a).

Note: Figures in parenthesis point to negative growth rates. 
50 and 1996-97. The annual growth of the crop production subsector has been slightly lower; and that of livestock, wheat, cotton and sugarcane slightly higher, than the average growth rate.

Secondly, the growth pattern in agriculture has been patchy: it has been enviable during certain periods but disappointing in others. The table shows that the growth rate of the value added by agriculture barely exceeded 1.0 percent per annum during the early 1950s and 2.1 percent during 1954-55 to 1959-60. The acceleration of growth initiated in the Fifties continued into the Sixties and agricultural value-added exhibited an annual growth rate of 3.78 percent and 6.26 percent, respectively, during the first and second halves. Lacking any change in livestock sector, the accelerating growth rates were the result of rising growth rates of crop production. The first and second halves of 1960s had respective annual growth rates of crop output of 4.8 to 8.2 percent. In the latter half of 1960s rice, wheat, cotton and sugarcane had annual increases of 12.2, 9.7, 7.3 and 7.2 percent per year.

During early Seventies the annual growth rate in agriculture plummeted to the historically lowest level of 0.78 percent. While crop production had a growth rate of 0.49 percent, output of rice, cotton and sugarcane fell persistently. With the exception of poultry, growth was equally disappointing in livestock sector. However, the agricultural growth revived in the second half of the Seventies and crop output and livestock registered respective growth rates of more than 4.0 and 3.0 percent.

Since the 1980s, livestock and non-cereal crops emerged as the prime movers of agricultural growth. Against 3.28 percent annual growth rate of agriculture, growth of livestock exceeded 4.77 percent and that of cotton 6.71 percent. By contrast respective growth rates of crop sector and cereal crops were less than 2.63 and 2.0 percent. During the period of 1984-85 and 1989-90, the production of cotton and livestock witnessed a further acceleration and contributed to more rapid agricultural growth (4.57 percent) than in the previous period. Despite some recovery in wheat, the growth rates of sugarcane and rice remained very low. In the 1990s, the growth rates fell further to less than 4.0 and 3.0 percent per annum respectively between 1989-90 and 1994-95 and 1994-95 and 1996-97. The high growth rates of the sugarcane and livestock sectors had a positive, and a slower growth of cotton, rice and wheat a negative, effect on the overall agricultural growth in the 1990s.

\section{TRENDS IN INCOME DISTRIBUTION AND POVERTY}

The time-series data on income distribution and poverty are not as comprehensive as those on agricultural production. The Household Income and Expenditure Surveys can profitably be used to trace the changes in the patterns of income distribution and poverty. Table 2 presents the relevant data on the inter-temporal income distribution and poverty trends in rural Pakistan. 
It is clear from Table 2 that the patterns of income distribution and poverty in rural Pakistan have witnessed considerable changes from time to time. The rural incomes became more skewed during early Sixties. Improvements in rural income distribution occurred during 1963-64 to 1970-71, as concentration ratios fell from 0.35 to 0.29 . A reversal of this trend began in 1971-72; and the rural income inequalities grew until 1984-85. Although rural income differentials narrowed down between 1984-85 and 1987-88, the Gini Coefficients rose to 0.41 and 0.37 respectively, the highest ever recorded in Pakistan's history, during 1990-91 and 1992-93. ${ }^{1}$

Table 2

Income Concentration Ratios and Poverty Levels in Rural Pakistan from 1959-60 to 1990-91

\begin{tabular}{lccc}
\hline & \multirow{2}{*}{$\begin{array}{c}\text { Gini Coefficients } \\
\text { Based on Household } \\
\text { Income }\end{array}$} & $\begin{array}{c}\text { Rural Population Below the Calorie-based } \\
\text { Poverty-line }\end{array}$ \\
\cline { 3 - 4 } Year & 0.35 & As a Percent of Total & Rural Poor (Million) \\
\hline 1959 & 0.36 & - & - \\
1961 & 0.35 & 43.10 & - \\
$1963-64$ & 0.32 & - & 16.53 \\
$1966-67$ & 0.29 & 25.10 & - \\
$1968-69$ & 0.30 & 26.00 & 10.76 \\
$1969-70$ & 0.29 & 9.25 & 11.40 \\
$1970-71$ & 0.31 & 19.19 & 4.15 \\
$1971-72$ & 0.33 & 19.00 & 8.82 \\
1979 & 0.34 & 21.10 & 11.48 \\
$1984-85$ & 0.33 & - & 14.33 \\
$1985-86$ & 0.32 & - & - \\
$1986-87$ & 0.31 & 19.60 & - \\
$1987-88$ & 0.41 & 20.60 & 14.30 \\
$1990-91$ & 0.37 & 20.40 & 16.06 \\
$1992-93$ & & & 16.36 \\
\hline
\end{tabular}

Source: Gini Ratios are from [Chaudhry (1982); and Government of Pakistan (1996a and 1997)]; while the data about Poverty Levels are from [Allauddin (1975); Ercelawn (1988) and Malik (1994)].

${ }^{1}$ The sudden rise in Gini may partly be attributed to variation in data used in the calculation of Gini Coefficients. Prior to 1990, the grouped data formed the basis of calculation but ungrouped household data were used for calculating Gini ratios for 1990-91 and 1992-93. 
The poverty level exhibited more or less the same trend as rural income distribution, though with less abrupt changes. This is to expected as poverty studies are based on expenditure which can be financed out of savings or borrowing. In 1963-64, poverty was widespread as more than 43 percent of the rural population suffered from varying degrees of poverty. The incidence of poverty fell consistently through the Sixties and was confined to 9 percent of the population by 1970-71. Relative poverty accentuated between 1970-71 and 1984-85 reaching a level of 21.1 percent. It, however, has tended to stabilise at around 20 percent in the late Eighties and early Nineties [Chaudhry (1996)].

There were at least 16.5 million rural poor in Pakistan during 1963-64. The number fell to around 11.0 million in 1968-69 and 1969-70. A sharp decline in absolute poverty occurred during 1970-71, but it has risen consistently since then with the result that the number of poor in 1992-93 were about the same as in 1963-64.

\section{FACTORS IN GROWTH AND DISTRIBUTION}

Pakistan's long-term experience in agricultural growth and distribution seems to be rich enough to allow some hypothesis testing. Such an analysis should help appropriate policy-making, to redirect the government's efforts, and enhancing the welfare of the people. Among the many hypotheses that can be tested on the basis of this experience, the most appropriate ones are listed below.

Firstly, we can ask: is there a trade-off between agricultural growth and income distribution? Secondly, what factors, other than the growth rate of output, may have been responsible for changing the trends in agricultural growth and income distribution? Thirdly, what has been the effect of agricultural price policy on growth, distribution and poverty alleviation?

\section{Growth and Distribution in Agriculture}

The policy of growth maximisation was widely criticised during the Sixties for its adverse effects on income distribution, and social, political and economic stability. However, several recent studies show that rapid growth of agricultural sector has been no less than a blessing for Pakistan. Naqvi (1994), for example, has shown that a sturdy agricultural growth is essential for rapid growth of national income, for attaining macroeconomic stability, and for securing an improvement in distributive justice and a reduction in rural poverty. According to Naqvi (1992) agriculture must maintain a growth rate of more than 5.0 percent in order to ensure achievement of the above desired objectives. That a 5.0 percent annual growth of agriculture output is an absolute necessity in Pakistan has further been enunciated by Mellor (1988) in terms of its implications for the effective employment of growing labour force. On the basis of population growth rates, an income elasticity of demand for food of 0.6 and a per capita 
income growth rate of 2-3 percent, Chaudhry (1994) argued that food output must grow at an annual rate of 5.0 percent to attain food self-sufficiency on a sustainable basis.

Can such high growth rates be achieved and sustained in the future? It may be recalled that Pakistan has had a long-term growth rate of nearly 3.3 percent per annum between 1949-50 and 1996-97. It may also be recalled that the average annual growth rate exceeded the required growth rate during 1960s and was close to it between 198485 and 1989-90. In view of this fact the current agricultural growth can easily be stepped up to the required growth rate by simple manipulation of agricultural policy.

\section{Technology and Growth}

It has been shown that agricultural growth may not be destabilising, and that the Green Revolution would have made a positive contribution to higher growth rate of agriculture. There is considerable evidence that private tubewell installations led to a 50 percent increase in the cropping intensity [Muhammad (1965)]. The shorter duration of the High-Yielding Varieties (HYVs) of wheat and rice and the availability of chemical fertilisers has produced similar results [Gill (1973)]. The quickness of operations permitted by tractor cultivation augmented the cropping-intensity effects of tubewells and HYVs [Lawrence (1970)]. The yield-increasing effect of the above technologies was equally important. Each of the tubewells and HYVs of wheat and rice raised crop yields by 50 percent [Muhammad (1965) and Gill (1973)]. The new varieties of cotton, introduced in the 1980s, have a yield potential of 3-4 times the traditional varieties [Chaudhry (1994)].

\section{Green Revolution and Inequalities}

A second hypothesis that needs to be tested is the (alleged) negative effect of the Green Revolution on rural income distribution. The argument is based on growing income differences among; (1) the small, and the large farms, (2) the farm sector and the landless workers, and (3) the irrigated and unirrigated areas. These issues are discussed below if only to portray a true picture.

\section{(a) Inter-farm Income Disparities}

In line with the existing literature, the changes in farm income are a function of the changes in land distribution and those in farm productivity. Assuming proportional changes in the productivity of the small and large farms, the changes in income distribution would follow the trend of land distribution. ${ }^{2}$ As measured by the operational and ownership holdings, land distribution trends over the years are depicted in Table 3.

\footnotetext{
${ }^{2}$ For the purposes of this study, small farms include all farms under 12.5 acres and large farms mean farms with farm area exceeding 25 acres.
} 
Table 3

Changes in the Distribution of Agricultural Land for Census Years

\begin{tabular}{lccc}
\hline \multirow{2}{*}{$\begin{array}{l}\text { Agricultural } \\
\text { Census Year }\end{array}$} & \multicolumn{3}{c}{ Land Concentration Relations: Based on } \\
\cline { 2 - 3 } & Revenue Factors & Census Data & \multirow{2}{*}{$\begin{array}{c}\text { Operational Holdings } \\
\text { Census Data }\end{array}$} \\
\hline 1960 & 0.640 & - & 0.617 \\
1972 & 0.570 & 0.658 & 0.518 \\
1980 & 0.510 & 0.643 & 0.535 \\
1990 & - & 0.654 & 0.583 \\
\hline
\end{tabular}

Source: [Naqvi, Khan and Chaudhry (1989) and Government of Pakistan (1993)].

It should be clear that land distribution in Pakistan consistently moved in favour of the small farmers between 1960 and 1980 . Both the revenue records and the census data show a rapid improvement in the distribution of ownership holdings. The same trend is reflected in the distribution of operational area during 1959-60 and 1972, but with a slight reversal occurring between 1972 and 1990. During the 1980s both the ownership and operational holdings show a deterioration of land distribution. These trends, especially during the Sixties, indicate that the Green Revolution may not have led to any large-scale land purchases, land renting or increased owner cultivation. While the improvements in land distribution continued to be guided by the Islamic inheritance laws, its deterioration in the Seventies and Eighties must have been induced by land purchases by the industrialists with a view to saving taxes on industrial profits [Government of Pakistan (1993a)].

There is an impressive body of empirical evidence which postulates an inverse size-productivity relationship in agriculture [Cornia (1985); Dorner (1972); Johnston and Tomich (1985) and Ruttan (1969)]. Despite contrary theoretical suggestions, empirical evidence in Pakistan lends support to the inverse relationship between farm size and agricultural productivity [Chaudhry (1982); Naqvi, Khan and Chaudhry (1989); Sharif et al. (1986) and Hai (1997)]. Some of factual information in this regard has been depicted in Table 4.

It is apparent from Table 4 that the gross productivity of the small farms has been consistently higher than that of the large ones. The last column of the table indicates that the small farms have maintained an edge over the large farms in the growth of land productivity between 1965-66 to 1995-96. In the light of the above, there is no room for the assertion that the large farms overtook the small farms in farm productivity under the Green Revolution. Indeed, the differences in the adoption rates of various modern technologies between the two groups have narrowed with passage of time. 
Table 4

Gross Productivities per Farm Acre for Small and Large Farms

\begin{tabular}{|c|c|c|c|}
\hline \multirow[b]{2}{*}{ Year } & \multicolumn{2}{|c|}{ Value of Output (Rs) per Farm Acre } & \multirow{2}{*}{$\begin{array}{l}\text { Small as Percentage of Large } \\
\text { Farm's Productivity }\end{array}$} \\
\hline & Small Farms & Large Farms & \\
\hline$\overline{1965-66}$ & 363 & 205 & 177.1 \\
\hline $1966-67$ & 515 & 250 & 206.0 \\
\hline $1967-68$ & 561 & 230 & 243.9 \\
\hline 1968-69 & 552 & 250 & 220.8 \\
\hline $1969-70$ & 657 & 349 & 188.2 \\
\hline 1970-71 & 700 & 332 & 210.8 \\
\hline $1973-74$ & 526 & 303 & 173.6 \\
\hline 1981-82 & 1719 & 1031 & 166.7 \\
\hline $1995-96$ & 7301 & 3419 & 209.3 \\
\hline
\end{tabular}

Source: [Naqvi, Khan and Chaudhry (1989) and Hai (1997)]. The figures reported here have been adjusted for land use intensities of the two groups and differ to that extent from incomes reported in the source.

It may be argued that, because of the lumpiness of investment, the ownership of the mechanical technologies like tubewells and tractors would be heavily concentrated in the hands of large farmers. Apparently this seems to be the case. According to the 1980 Census of Agriculture [Government of Pakistan (1983)], nearly 59 percent of the tractors and about 39 percent of the tubewells were in the ownership of large farmers. By contrast, the small farmers owned only 16 percent of the tractors and 35 percent of the tubewells. However, if measured in terms of per unit of farm area, the disparity of ownership of mechanical inputs between small and large farmers is considerably reduced. Furthermore, the relative differences in the physical ownership of mechanical inputs may not be uniquely related to inter-farm differences in productivity levels and the efficiency of resource use. The reason is simple. The use of these inputs may not always be positively related to the ownership pattern. This is because the practice of selling tubewell water and the institution of contract-ploughing at competitive rates can increase the small farmer's access to tubewell and tractor services. Accounting for this fact, nearly 35 and 32 percent of the small farmers were users of tractors and tubewells. By contrast, the respective percentages were 44 and 33 for the large farmers.

As regards the current adoption rates of bio-chemical technology, there are no known differences between the small farms and the large farms. Although the leading role of the large farms in the adoption of HYVs cannot be denied, there is considerable evidence that the differences in the adoption rates of the two groups had at least disappeared by the early Seventies [Chaudhry (1982)]. It may be interesting to note that the HYVs of wheat accounted for 68 percent of wheat acreage in 1980, on both the 
small farms and the large farms. By contrast, the small farms devoted nearly 54.0 percent of their rice area to HYVs of rice compared to 44.0 percent on large farms [Government of Pakistan (1983)].

Not very different has been the experience with chemical fertilisers. There were wide differences in the rates of fertiliser application on large farms and the small farms in the Sixties [Chaudhry (1982)]. However, such differences had been greatly reduced by the early 1980s [Naqvi, Khan and Chaudhry (1989)].

One of the most probable reasons for a somewhat lesser use of the modern inputs on the small farms relative to the large ones lies in the fact that the small farms, guided by their resource endowments, prefer to make a more intensive use of some of the traditional inputs. For example, although tractors may enable the large farms to undertake tillage operations with precision, small farms can do the same in better ways with greater inputs of human labour and animal power in addition to their access to tractors. According to available evidence [Naqvi, Khan, and Chaudhry (1989); Herring and Chaudhry (1974) and Chaudhry (1982)], the labour input per unit of land for the small farms is, at least, twice as much as that for the large farms. Similarly, the bullockpower input of the small farmers was 4.0 times that of the large farmers. Although the small farmers have a somewhat limited access to tubewell water, their proportionate irrigated area has historically exceeded that of the large farmers, probably because they tend to use water more efficiently. This would be particularly true if the small farmers had only a limited access to surface and ground water supplies. According to the 1990 Census of Agriculture [Government of Pakistan (1993)], the proportionate irrigated area of the small farmers was close to 80.5 percent as against 72.8 percent of that of the large farmers. A somewhat lesser use of chemical fertiliser on the small farms is perhaps more than offset by their higher manorial input. Also, the small farmers use twice as much farmyard manure per acre as is done by large farmers [Chaudhry (1982)]. As farm-yard manure is rich in plant nutrients, its greater use would be instrumental in enabling the small farmers to secure a higher and better soil-nutrient balance than is obtained by large farmers, who solely depend on chemical fertilisers.

\section{(b) Incomes of Rural Landless and Landowners}

Apart from the relative income changes of the small farms and the large farms, the pattern of income distribution is critically shaped by the relative growth rates of the incomes of the landless and the landowners, which are in turn determined by the changes in employment and wages in agriculture. This issue is discussed in the following pages.

On the basis of Labour Force Surveys, Chaudhry and Chaudhry (1992) have shown that the employment rates in rural Pakistan were above 98 percent during the 1960s and early 1970s, fell below the 97 percent level in the late Seventies and the Eighties, and exceeded the 94-95 percent level in the 1990s. 
The changes in the demand for, and the supply of, labour in agriculture determine long term trends in rural employment. While the labour supply is a function of the growth of rural labour force, its demand depends directly on the growth of agricultural output. The growth of labour force in agriculture between 1951-81 has been estimated at 2.10 percent per annum [Rukanuddin and Farooqui (1988)], and at 1.95 percent between 1979-80 and 1994-95 [Government of Pakistan (1996)]. Using the estimates of the employment elasticity of agricultural growth given in Mellor (1988), it is not difficult to estimate the growth of labour demand in agriculture. Given this elasticity, agriculture must at least maintain a growth rate of $3.0-3.5$ percent per year. However as the growth rates of agriculture remained below these threshold levels during the 1950s, the 1970s, the early 1980s and the 1990s, a deterioration in employment situation should be expected. On the contrary, the high growth rates in the 1960s and the second the half of the 1980s may be compatible with an increasing competition in the rural labour market. Needless to add that a large growth of demand for agricultural labour was the result of technological breakthroughs in agriculture like the Green Revolution of the Sixties and the HYVs of cotton during the late 1980s [Chaudhry and Chaudhry (1992)].

The intertemporal trend of rural wages is another factor in determining rural income distribution. The relevant data are given in Table 5.

Table 5

Trends in Agricultural Wages from 1959-60 to 1994-95

\begin{tabular}{lcccc}
\hline Year & $\begin{array}{c}\text { Agricultural Wage } \\
\text { Rate (Rs per day) }\end{array}$ & $\begin{array}{c}\text { Implicit GDP } \\
\text { Deflator }\end{array}$ & $\begin{array}{c}\text { Real Wage } \\
\text { Rate }\end{array}$ & $\begin{array}{c}\text { Annual Growth } \\
\text { Rate }\end{array}$ \\
\hline $1959-60$ & 1.36 & 100 & 1.36 & - \\
$1964-65$ & 1.92 & 112.53 & 1.71 & 4.69 \\
$1969-70$ & 3.00 & 126.96 & 2.36 & 6.65 \\
$1974-75$ & 7.53 & 256.49 & 2.94 & 4.49 \\
$1979-80$ & 13.30 & 392.80 & 3.39 & 2.89 \\
$1984-85$ & 21.93 & 585.34 & 3.75 & 2.04 \\
$1989-90$ & 32.62 & 709.95 & 4.60 & 4.17 \\
$1994-95$ & 56.00 & 1290.74 & 4.34 & -1.12 \\
\hline
\end{tabular}

Source: [Chaudhry and Chaudhry (1992); Pakistan Labour Gazette (Various Years); Monthly Statistical Bulletin (Various Years); and Government of Pakistan (1996a)]

Several interesting conclusions follow from the table. The nominal daily-wage rate in 1959-60 was indeed low, not exceeding Rs 1.36 per day. It took 10 years to double, but a redoubling of these rates took just five years between 1969-70 and 197475. A nearly three-fold increase seems to have occurred during each of ten-year periods 
beginning with 1974-75 and 1984-85. In contrast, when the real GDP deflators is used, the real wages in agriculture, show an inconsistent and varying intertemporal trend. The growth was the fastest during Sixties, exceeding 6.6 percent per annum during the second half of the decade. The annual growth rates declined and averaged around 4.5, 2.9 and 2.0 percent respectively during first and second halves of the Seventies and the early 1980s. While the real wages grew at an annual rate of 4.2 percent during 1984-85 to 1989-90, they began to decline at the rate of 1.1 percent in the 1990s.

On the basis of the rates of increase in agricultural employment (2.00 percent) and the real wage, the growth rate of the 'wage fund' (defined as the product of number of persons employed in agriculture and the going wage rate) can be calculated and compared with the estimates of value added in agriculture to draw its implications for rural income distribution and poverty. Going by these comparisons, the income distribution and poverty witnessed considerable improvement during the 1960s and second half of the 1980s; but the trend reversed over the 1969-70 to 1984-85 and the 1989-90 to 1994-95 period.

\section{(c) The State of Regional Disparities}

It was argued in the late Sixties that the regional income distribution would inevitably worsen because the Green Revolution technologies were heavily concentrated in the most prosperous province of Punjab with well-developed irrigation system to the total exclusion of poorest regions like Balochistan, the barani areas were supposed to have least access to assured water supply [Falcon (1970) and Hamid and Hussain (1974)]. These arguments have, however been widely challenged in the more recent literature [Pinstrup-Anderson (1985) and Chaudhry and Iqbal (1989)]. At any rate, whatever validity such argument had for the pioneer adopters of these technologies the same may not hold for the late-comers, who tend to adopt the technologies more rapidly once their benefits are fully demonstrated. In fact, it has been shown that, following the Punjab's example, other provinces and the barani areas have adopted the Green Revolution technologies at an even faster rate [Chaudhry and Iqbal (1989)].

The question is: have the benefits of Green Revolution been concentrated in the Punjab relative to Balochistan and the barani areas? In the absence of any published statistics on regional incomes, the question can be investigated in the light of the yield trends of wheat and rice crops widely grown in all the above regions. Table 6 furnishes the necessary details.

The table makes clear that, contrary to the notions held in the 1960s, the Green Revolution has had a much greater success in Balochistan and in the barani areas than in the Punjab. While the wheat yields doubled in Punjab between 1964-65 and 1994-95, they tripled or tetraploid in Balochistan and barani areas. And even though rice is not grown in the barani areas, the rice yields have at least doubled in Balochistan as against the stagnation in the Punjab. 
Table 6

Wheat and Rice Yields in the Punjab, Balochistan and Barani Areas for Selected Years since 1964-65

\begin{tabular}{|c|c|c|c|c|c|}
\hline \multirow[b]{3}{*}{ Years } & \multicolumn{5}{|c|}{ Crop Yields (Kgs. per Hectare) of: } \\
\hline & \multicolumn{3}{|c|}{ Wheat } & \multicolumn{2}{|c|}{ Rice } \\
\hline & Punjab & Balochistan & Barani & Punjab & Balochistan \\
\hline $1964-65$ & 1020 & 600 & - & 1190 & 980 \\
\hline 1969-70 & 1360 & 770 & 397 & 1580 & 990 \\
\hline $1974-75$ & 1490 & 980 & 572 & 1520 & 1110 \\
\hline $1979-80$ & 1598 & 1229 & 877 & 1287 & 2223 \\
\hline 1984-85 & 1610 & 1576 & 780 & 1370 & 2762 \\
\hline $1989-90$ & 1882 & 1902 & 1033 & 1157 & 2618 \\
\hline 1994-95 & 2153 & 2320 & 1129 & 1257 & 1911 \\
\hline
\end{tabular}

Source: Government of Pakistan $(1981,1996)$.

\section{Agricultural Price Policy and Development}

The next question to be addressed is: are prices important in shaping agricultural development and can non-price factors play their usual role in the absence of remunerative prices? There is worldwide evidence that prices play a crucial role in agricultural development. In particular, the long-term trends in agricultural commodity prices relative to input prices influence expectations, investment and technology and hence the growth of agricultural production [Timmer (1988)]. Also, stable and remunerative prices of farm products are associated with a reduction of risk and uncertainty; and they augment entrepreneurial skills of the farming community [Schultz (1978)]. Finally, the movements in the intersectoral terms of trade influence the unemployment rate, the wage good prices, the pattern of income distribution, and the level of social welfare [Brown (1978)]. The conclusion seems to be that the non-price factors (technological and institutional) are not a substitute for an effective price mechanism. For example, Bale and Lutz (1981) highlight the fact that the level of agricultural production depends not so much on technical considerations but, in large measure, on what governments do to agriculture. According to Schultz (1978) whenever the farm product is underpriced, even though superior varieties of crops are at hand, the adoption rate is at best partial. In the same vein, Johnston and Cownie (1969) have remarked that the application of chemical fertilisers will depend on optimal grainfertiliser price ratios. Schultz (1965) has categorically stated that when the price of fertiliser is far above the prices of farm products, no extension programme can induce the farmers to use additional quantities of fertiliser. 
As is well known, Pakistan has always followed a policy of intervention in the price mechanism, to the point of subverting it. In the Fifties, for example, most of the agricultural commodities were subjected to compulsory procurement at substantially less than the world prices. However, this policy was relaxed in the 1960s and the government began to guarantee above-world prices of agricultural commodities, along with liberal subsidies on fertilisers, pesticides, tubewells, tractors and improved seeds of agricultural commodities [Kuhnen (1989)]; but the policy was reversed again in the beginning of 1970s, and the prices of agricultural commodities were reduced to less than world levels, while those of fertilisers were tripled [Haque (1993)].

In the 1980s and 1990s, a different set of conditions determined the fate of agricultural price policy. Under the World Bank/IMF structural adjustment programme, the government subsidies on pesticides, seeds and mechanisation were withdrawn and the subsidy on fertiliser was to be phased out. At the same time, in view of expected increases of prices and rising profits on major inputs the sales of substandard fertilisers and pesticides, black marketing and underbagging became the standard practices. To avoid agitation from the urban consumers and industrialists, the governments in power continued to maintain agricultural commodity prices well below the world prices. This has been the conclusion of all the studies undertaken during the Eighties and the Nineties [Chaudhry and Kayani (1991); Dorosh and Valdes (1990); Ender (1992); Faruquee (1995); Longmire and Debord (1993) and Government of Punjab (1991)]. Table 7 sums up the situation since 1979-80.

It follows from Table 7 that, while nominal protection coefficients moved up and down randomly, the underpricing of agricultural commodities has remained a consistent policy. As a consequence, the resource transfer from agriculture (net of input subsidies and government expenditure on agriculture and water) has greatly increased: it was Rs 11 billion until about mid-Eighties, averaged around Rs 20 billion during the second half of the decaded, has been well above Rs 30 billion during 1990-93, and reached an alltime high figure of Rs 66 billion in 1994-95.

While the above resource outflows are large enough to dry up any investment potential of the farm sector, the story does not end here. In view of the faster increases in input prices relative to those of final goods, agriculture has faced low and falling rates of profits [Afzal et al. (1992)] in sharp contrast to rising and substantially higher profit rates of industrial sector [Government of Punjab (1991)]. Given this state of affairs, it is only rational on the part of the marginal investor to disinvest in agriculture and redirect investible funds into the industrial sector.

As appropriate incentives are a sine qua non for rapid agricultural growth, the favourable price policy of the Sixties did induce heavy private investments, which led to a rapid growth in agriculture; but as the price incentives became less favourable during the 1980s and 1990s, they induced falling growth rates of agricultural crops. In addition 
Table 7

Extent of Underpricing of Agricultural Commodities and Resource Transfers from Agriculture, 1979-80 to 1994-95

\begin{tabular}{|c|c|c|c|c|c|c|c|c|c|c|c|c|c|c|}
\hline \multirow[b]{2}{*}{ Years } & \multicolumn{5}{|c|}{ Nominal Protection Coefficients } & \multirow[b]{2}{*}{$\begin{array}{l}\text { Agriculture } \\
\text { (Rs Million) }\end{array}$} & \multicolumn{2}{|c|}{$\begin{array}{l}\text { Gross Transfer } \\
\text { from }\end{array}$} & \multicolumn{4}{|c|}{ Input Subsidies (Rs Million) in Agriculture on: } & \multirow[b]{2}{*}{ fers } & \multirow[t]{2}{*}{$\begin{array}{l}\text { Govt. } \\
\text { Expenditure }\end{array}$} \\
\hline & Cotton & Wheat & $\begin{array}{c}\text { Basmati } \\
\text { Rice }\end{array}$ & $\begin{array}{c}\text { Coarse } \\
\text { Rice } \\
\end{array}$ & $\begin{array}{l}\text { Sugar } \\
\text { Cane } \\
\end{array}$ & & Fertiliser & $\begin{array}{c}\text { Irrigation } \\
\text { Water }\end{array}$ & $\begin{array}{l}\text { Govt. } \\
\text { Credit }\end{array}$ & Electricity & Total & $\begin{array}{l}\text { on Agr. \& } \\
\text { Water }\end{array}$ & & \\
\hline 1979-80 & 0.57 & 0.57 & 0.28 & 0.47 & 0.38 & 12847 & 2455 & 297 & 116 & -16 & 3121 & 4891 & 4835 & \\
\hline 1980-81 & 0.51 & 0.47 & 0.32 & 0.41 & 0.39 & 18665 & 2448 & 338 & 180 & -88 & 2898 & 4956 & 10809 & \\
\hline 1981-82 & 0.68 & 0.44 & 0.29 & 0.43 & 0.50 & 18128 & 1750 & 416 & 265 & -11 & 2444 & 6235 & 9449 & \\
\hline 1982-83 & 0.60 & 0.50 & 0.33 & 0.74 & 0.73 & 15029 & 1948 & 437 & 349 & -100 & 2658 & 7297 & 5074 & \\
\hline 1983-84 & 0.50 & 0.37 & 0.33 & 0.73 & 0.77 & 19707 & 1466 & 661 & 524 & -153 & 2498 & 6179 & 11080 & \\
\hline 1984-85 & 0.52 & 0.39 & 0.25 & 0.56 & 1.29 & 20546 & 1500 & 828 & 543 & 103 & 2974 & 6461 & 11111 & \\
\hline 1985-86 & 0.69 & 0.51 & 0.24 & 1.89 & 0.94 & 17313 & 2409 & 1005 & 448 & 16 & 3894 & 9024 & 4395 & \\
\hline 1986-87 & 0.76 & 0.43 & 0.24 & 1.96 & 1.25 & 20038 & 1284 & 1234 & 551 & 375 & 3444 & 444 & & \\
\hline 1987-88 & 0.43 & 0.41 & 0.28 & 0.67 & 1.41 & 40162 & 1995 & 1352 & 785 & 1112 & 5259 & 31 & 26872 & \\
\hline 1988-89 & 0.49 & 0.41 & 0.29 & 0.47 & 1.09 & 35059 & 2415 & 1154 & 1009 & 1139 & 5720 & 7379 & 21960 & \\
\hline 1989-90 & 0.34 & 0.39 & 0.33 & 0.41 & 0.47 & 72226 & 1257 & 1028 & 1207 & 1380 & 4872 & 8452 & 58902 & \\
\hline 1990-91 & 0.39 & 0.57 & 0.53 & 1.19 & 0.62 & 57614 & 1248 & 1545 & 1526 & 1625 & 6220 & 9857 & 41537 & \\
\hline 1991-92 & 0.47 & 0.52 & 0.59 & 1.10 & 0.74 & 51591 & 1191 & 2701 & 1744 & 1796 & 7512 & 9446 & 34633 & \\
\hline 1992-93 & 0.55 & 0.53 & 0.58 & 0.79 & 0.77 & 44354 & 810 & 3111 & 1993 & 1724 & 7639 & 11922 & 24793 & \\
\hline 1993-94 & 0.55 & 0.69 & 0.53 & 0.93 & 0.82 & 43543 & 805 & 2565 & 1980 & 330 & 5680 & 14429 & 23434 & \\
\hline 1994-95 & 0.40 & 0.60 & 0.66 & 1.01 & 0.59 & 87746 & 79 & 2938 & 1986 & 330 & 5333 & 16113 & 66300 & \\
\hline 1995-96 & 0.48 & 0.47 & 0.71 & 0.77 & 0.58 & 77414 & 0 & NA & 0 & NA & NA & 16508 & NA & \\
\hline 1996-97 & 0.57 & 0.65 & 0.60 & 0.95 & 0.79 & 56144 & 0 & NA & 0 & NA & NA & 17487 & NA & \\
\hline
\end{tabular}

Source: [Chaudhry (1995). Chaudhry and Maan (1993) and Chaudhry and Sahibzada (1995)].

Nominal protection coefficients represent the ratios of procurement to the corresponding import/export parity prices and net transfers equal to gross transfers minus subsidies and government expenditure on agriculture and water. 
to the obvious repercussions for agriculture, the unhelpful price policy in vogue since 1980 has had adverse effects on the landless and rural poor as well. A growth rate of 2-3 percent of agriculture crops is highly inadequate to absorb the growing labour force and the rising unemployment is likely to induce large undesirable effects on income distribution and rural poverty. Low agricultural commodity prices also tend to accentuate poverty and income differentials among the farmers for at least two reasons. First, the implicit taxation of agriculture in the form of the low prices of agricultural produce increases the skewness of post-tax disposable incomes. Second, the impact of the increase in input prices on output is likely to be much worse on the small farmers relative to the big farmers because of the former's risk-averse character. It has been noted, for example, that small farms - those with a farm size of less than 5.0 acrestend to reduce fertiliser input by 2.4 percent with each 1.0 percent increase in fertiliser prices in contrast to price elasticity of demand for fertiliser of only 0.6 percent on large farms [NFDC (1994)]. It is thus not surprising that an unfavourable price policy in agriculture, since 1980, was responsible not only for the slower growth of agricultural output but also for worsening income distribution and poverty levels.

\section{CONCLUSIONS AND POLICY RECOMMENDATIONS}

The main objective of this paper has been to review Pakistan's historical experience in agricultural development in terms of growth, income distribution and rural poverty. While the long-term growth rates between 1949-50 and 1994-95 have been satisfactory, the variations around the average have been rather too large over the various decades. Beginning with a stagnating sector of the 1950s, agriculture witnessed record growth rates during the Sixties. This was followed by the lowest growth rates of the early Seventies, and then acceleration in the second half of the Seventies. The experience since 1979-80 has bee mixed, but the growth rates have been rather low through the Eighties and the Nineties. The trends in income distribution and poverty varied directly with the agricultural growth rates, especially when they were in excess of the thresh-hold level of 4.5-5.0 percent per annum. In general, a growth rate of 5.0 percent or higher has induced positive changes in income distribution and poverty. In view of this positive association, the pursuit of a high growth policy in agriculture should guide Pakistan's future development strategy. The efficiency of resource use, a greater dependence on modern technologies, and a minimisation of government intervention in the market mechanism are the essential pillars of the high growth strategy, which has the following as its elements.

Firstly, technological change is at the heart of a high growth-strategy. To this end, there is need to evolve new HYVs of crops, new breeds of livestock and to develop new cultural practices. To accomplish these tasks effectively, the importance of greater 
expenditure on research can hardly be underestimated.

Secondly, from the growth maximisation viewpoint, the efficiency of input delivery systems should be enhanced. In order to check black marketing, underbagging and the sale of substandard fertilisers, pesticides and seeds, punitive action should be taken. In addition, efforts should be made to reduce the intensity of the problem by open market sales, by breaking up government (and registered dealer) monopolies, and by ensuring supply of inputs at the right price, time and place and in adequate quantities. In the case of irrigation water, an efficient use of available supplies must be ensured by the construction of storage dams, a continuation of water-course improvement programme, an equitable distribution of water across watercourses and the establishment of a direct relationship between the quantum of water delivered and the charges levied on its use. However, being a public good, the privatisation of the irrigation system, partial or otherwise, is not desirable.

Thirdly, the government intervention in agricultural commodity markets should be reduced to a minimum. This follows from the fact that parastatals have widely been blamed for serving their own vested interests rather than the interests of producers and consumers [Bale (1985)]. However, such a policy should keep in view the fact that the experience with private traders in Pakistan has been disappointing so far [Naqvi and Cornelesse (1986)]. Thus appropriate laws should be framed to guard against illicit practices of the private sector to ensure fair play and competition in the agricultural commodity markets.

Finally, agricultural commodity prices should be raised to world levels in accordance with corresponding import and export parity prices to prevent an uneconomic (implicit) resource transfer from agriculture to other sectors of the economy. As procurement prices in Pakistan are still considerably below the world levels, raising them to world prices should revive incentives, investment and growth in agriculture. Even though the procurement price of wheat has been raised to Rs 240.00 per $40 \mathrm{kgs}$, the above statement would still hold as the average border price (cif Karachi) of imported wheat was in excess of Rs 310.00 per maund [Government of Pakistan (1996a)]. It is worth noting that this border price corresponded with an import parity price of wheat of Rs 360.00 .

\section{REFERENCES}

Afzal, Muhammad et al. (1992) Review of Prices of Agricultural Inputs and Outputs. Pakistan Journal of Agricultural Economics 1: 2 1-11.

Alauddin, Talat (1975) Mass Poverty in Pakistan: A Further Study. The Pakistan Development_Review 14: 4 431-450.

Aresvik, Odd Var (1967) Strategy and Outlook for Agricultural Development in West Pakistan. Paper prepared for the Symposium on Strategy of Agricultural Planning in Developing Countries held at University of Sindh. (Mimeo.) 
Bale, Malcolm, and Ernst Lutz (1981) Price Distortions in Agriculture and their Effects: An International Comparison. American Journal of Agricultural Economics 63: 1 822.

Bale, Malcolm and Ernst Lutz (1985) Agricultural Trade and Food Policy: The Experience of Five Developing Countries. Washington, D.C.: The World Bank. (World Bank Staff Working Paper No. 724.)

Brown, Gilbert T. (1978) Agricultural Pricing Policy in Developing Countries. In T. W. Schultz (ed) Distortions of Agricultural Incentives. Bloomington: Indiana University Press.

Brown, Lester R. (1970) Seeds of Change: The Green Revolution and Development in the 1970s. New York, Washington and London: Praeger Publishers.

Chaudhry, M. Ghaffar (1982). Green Revolution and Redistribution of Rural Incomes: Pakistan's Experience. The Pakistan Development Review 21:3 173-205.

Chaudhry, M. Ghaffar and A. H. Maan (1993) Taxation of Agriculture in Pakistan: Structure, Magnitude and Economic Implications. Pakistan Association of Agricultural Social Scientists. Islamabad, 196-206.

Chaudhry, M. Ghaffar and Shamim A. Sahibzada (1995) Agricultural Input Subsidies in Pakistan: Nature and Impact. The Pakistan Development Review 34:4 711-722.

Chaudhry, M. Ghaffar, and Ghulam Mustafa Chaudhry (1992) Trends of Rural Employment and Wages in Pakistan. The Pakistan Development Review 31:4 803812.

Chaudhry, M. Ghaffar, and Ghulam Mustafa Chaudhry (1994) Transformation of Agriculture, Food Self-sufficiency and Prospects for Surpluses: The Case of South Asia. Contemporary South Asia 3:1 37-52.

Chaudhry, M. Ghaffar, and Ghulam Mustafa Chaudhry (1995) Recent Input-Output Price Policy in Pakistan's Agriculture: Effects on Producers and Consumers. The Pakistan Development Review 34:1 1-23.

Chaudhry, M. Ghaffar, and Ghulam Mustafa Chaudhry (1996) Abolishing Poverty and Hunger: A South Asian Perspective. Contemporary South Asia 5:3 243-251.

Chaudhry, M. Ghaffar, and Nighat Naheed Kayani (1991) Implicit Taxation of Pakistan's Agriculture: An Analysis of the Commodity and Input Prices. The Pakistan Development Review 30:2 225-242.

Chaudhry, M. Ghaffar, and Zafar Iqbal (1989) Regional Distribution of Agricultural Incomes in Pakistan: An Intertemporal Analysis. The Pakistan Development Review 27:4 537-550.

Cheong, Kee Cheok, and Emmanuel H. D’Silva (1984) Prices, Terms of Trade and the Role of Government in Pakistan's Agriculture. Washington, D.C.: World Bank. (World Bank Staff Working Paper No. 643.)

Cornia, Giovanni Andreu (1985) Farm Size, Land Yields and the Agricultural 
Production Function: An Analysis for Fifteen Developing Countries. World Development 13:4 513-534.

Dorner, Peter (1972) Land Reforms and Economic Development. Harmondsworth: Penguin Books.

Dorosh, Paul, and Alberto Valdes (1990) Effects of Exchange Rate and Trade Policies on Agriculture in Pakistan. International Food Policy Research Institute, Washington, D.C.: (Research Report No. 84.)

Ender, Gary (1992) The Use of Producer and Consumer Subsidy Equivalents to Measure Government Intervention in Agriculture: The Case of Pakistan. Pakistan Journal of Agricultural Economics 1:1 24-59.

Ercelawn, A. A. (1988) Tables Presented at World Bank Seminar.

Falcon, W. P. (1970) The Green Revolution: Second Generation Problems. American Journal of Agricultural Economics 52: 698-710.

Faruquee (1995) Structural and Policy Reforms for Agricultural Growth: The Case of Pakistan. Washington, D.C.: The World Bank.

Gill, Amjad A. (1973) Pakistan Agricultural Development and Trade. Washington, D.C.: USDA, Economic Research Service.

Hai, Akhtar (1997) Selected Tables: Highlighting Basic Findings of Farm Credit Study as Part of Rural Financial Markets Study. Applied Economic Research Centre, Karachi. (Mimeo.)

Hamid, Naved, and Akmal Hussan (1974) Regional Inequalities and Capitalist Development. Pakistan Economic and Social Review 12:3 255-288.

Haque, Nadeem Ul (1993) Agricultural Pricing Policy in Pakistan. International Food Policy Research Institute, Washington D.C. (Mimeo.)

Herring, Ronald, and M. Ghaffar Chaudhry (1974) The 1972 Land Reforms in Pakistan and their Economic Implications: A Preliminary Analysis. The Pakistan Development Review 13:3.

Johnston, B. F., and John Cownie (1969) The Seed-fertiliser Revolution and Labour Force Absorption. American Economic Review 59:4 1-25.

Johnston, B. F., and Thomas P. Tomich (1985) Agricultural Strategies and Agrarian Structure. Development Review 3:2 1-37.

Kuhnen, Frithjof (1989) The Agrarian Sector in Pakistan's Development ProcessHistorical Evidence and Implications for Policy and Theory. The Pakistan Development Review 28: 4 509-528.

Lawrence, Roger (1970) Some Economic Aspects of Farm Mechanisation in Pakistan. Rawalpindi, Ford Foundation. (Mimeo.)

Longmire, Jim, and Pascale Debord (1993) Agricultural Pricing and Comparative Advantage in Pakistan: An Update to 1991-92. Report prepared for the South Asian Division of the World Bank, Washington, D.C.

Malik, Sohail J. (1988) Lectures on Agricultural Growth and Employment. Islamabad, 
Pakistan Institute of Development Economics. (Lectures in Development Economics, No. 7.)

Malik, Sohail J. (1994) Poverty in Pakistan: 1984-85, 1987-88 and 1990-91. International Food Policy Research Institute, Washington, D.C. (Mimeo.)

Mellor, John W. (1988) Lectures on Agricultural Growth and Employment. Islamabad: Pakistan Institute of Development Economics.

Muhammad, Ghulam (1965) Private Tubewell Development and Cropping Patterns in West Pakistan. The Pakistan Development Review 5:1 1-53.

Nabi, Ijaz, Naved Hamid, and Anjum Nasim (1990) Trade, Exchange Rate and Agricultural Pricing Policies in Pakistan: World Bank Comparative Study. Washington, D.C.: World Bank.

Naqvi, Syed Nawab Haider, and P. A. Cornelisse (1986) Public Policy and Wheat Market in Pakistan. The Pakistan Development Review 25:2 99-126.

Naqvi, Syed Nawab Haider, Mahmood Hasan Khan, and M. Ghaffar Chaudhry (1989) Structural Change in Pakistan's Agriculture. Islamabad: Pakistan Institute of Development Economics.

Naqvi, Syed Nawab Haider, Mahmood Hasan Khan, and M. Ghaffar Chaudhry (1992) On Raising the Level of Economic and Social Well-being of the People. Islamabad: Pakistan Institute of Development Economics.

Naqvi, Syed Nawab Haider, Mahmood Hasan Khan, and M. Ghaffar Chaudhry (1994) How Fast Should Agriculture Be Growing. Islamabad: Pakistan Institute of Development Economics.

NFDC (1994) Spot Checking of Fertiliser Sale and Price Position During Kharif. Islamabad: National Fertiliser Development Centre.

Pakistan, Government of (1981) Agricultural Statistics of Pakistan 1980. Islamabad: Ministry of Food, Agriculture and Cooperatives.

Pakistan, Government of (1983) Pakistan Census of Agriculture 1980: All Pakistan Report. Lahore: Agricultural Census Organisation.

Pakistan, Government of (1986) Pakistan Economic Survey 1985-86. Islamabad: Finance Division.

Pakistan, Government of (1993) 1990 Census of Agriculture: All Pakistan Report. Lahore: Agricultural Census Organisation.

Pakistan, Government of (1993a) Report of Prime Minister's Task Force on Agriculture. Islamabad: Revenue Division.

Pakistan, Government of (1995) Economic Survey 1994-95. Islamabad.

Pakistan, Government of (1996) Agricultural Statistics of Pakistan 1994-95 and Statistical Supplement 1995-96. Islamabad: Ministry of Food, Agriculture and Livestock.

Pakistan, Government of (1996a) Economic Survey 1995-96. Islamabad: Finance Division. 
Pakistan, Government of (1997) Economic Survey 1996-97.

Pinstrup-Anderson, P., and Peter B. R. Hazell (1985) The Impact of the Green Revolution and Prospects for the Future. Food Review International. 1:1 1-25.

Punjab, Government of (1991) Report of the Input-Output Price Review Committee. Lahore.

Rukanuddin, Abdul Razzaque, and M. Naseem Iqbal Farooqui (1988) The State of Population in Pakistan. Islamabad: National Institute of Population Studies.

Ruttan, Vernon W. (1969) Equity and Productivity Issues in Modern Agrarian Reform Legislation. In Ugo Papi and Charles Nunn (eds) Economic Problems of Agriculture in Industrial Societies. New York: St. Martin's Press.

Schultz, T. W. (1965) Economic Crisis in World Agriculture. Ann Arbor: University of Michigan Press.

Schultz, T. W. (1978) Constraints on Agricultural Production. In T.W. Schultz (ed) Distortions of Agricultural Incentives. Bloomington: Indiana University Press.

Sharif, M. et al. (1986) Constraints Facing Small Farmers in Punjab. Punjab Economic Research Institute, Lahore.

Timmer, C. Peter (1988) The Agricultural Transformation. In Hollis B. Chenery and T.N. Srinivasan (eds) Handbook of Development Economics. 1: Amsterdam: North Holland.

World Bank (1991) Pakistan: Current Economic Situation and Prospects. Washington, D.C.: World Bank. (Report No. 9283-PAK.) 